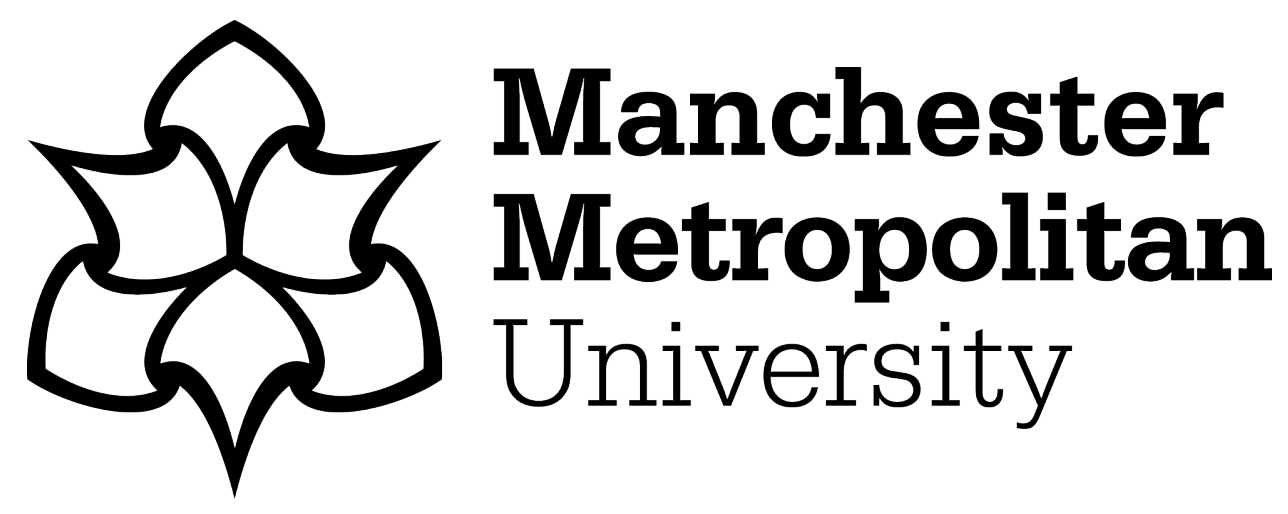

Nobrega, JHC, Pio, PGC, Fernandes, GL, Botêlho, ST, Araujo, TC, Anholon, R, Ordóñez, REC, Rampasso, IS, Leal Filho, W and Quelhas, OLG (2019) Sustainability in manufacturing processes: practices performed in metal forming, casting, heat treatment, welding and electrostatic painting. International Journal of Sustainable Development and World Ecology, 26 (8). pp. 684-697. ISSN 1350-4509

Downloaded from: https: //e-space.mmu.ac.uk/623791/

Version: Accepted Version

Publisher: Taylor \& Francis

DOI: https://doi.org/10.1080/13504509.2019.1655111

Please cite the published version 


\title{
Sustainability in manufacturing processes: practices performed in metal forming, casting, heat treatment, welding and electrostatic painting
}

\author{
Nobrega JHC, Pio PGC, Fernandes GL, Botêlho ST, Araujo TC, Anholon R, \\ Ordóñez REC, Rampasso IS, Leal Filho W, Quelhas OLG \\ International Journal of Sustainable Development and World Ecology 01 Jan 2020 \\ DOI \\ https://www.tandfonline.com/doi/full/10.1080/13504509.2019.1655111
}

\begin{abstract}
This article aims to list the main sustainable practices developed in the processes of metal forming, casting, heat treatment, welding and electrostatic painting. When analysed the literature about sustainable manufacturing, a predominance of studies about machining is observed and the processes mentioned are few explored in academic studies. The research strategy used to reach the objective was systematic literature review, conducted for each process cited. Many sustainable practices were identified with prominence of better materials use and energy efficiency. The authors of this article believe that the information presented here can be useful for researches in their future studies and for industry professionals interested in improving manufacturing processes.
\end{abstract}

Keywords: Sustainability; Manufacturing Processes; Literature Review.

\section{Introduction}

There are many definitions for the term "sustainable development". A widely used definition is presented in the report "Our Common Future" published in the 1980s. According to the mentioned document, sustainable development is: "meeting the needs of the present without compromising the ability of future generations to meet their own needs" (Brundtland 1987, p. 16). In this sense, United Nations (UN), established 17 Sustainable Development Goals (SDG) in order to propose guidelines to be followed. Within these goals, sustainable manufacturing is focused through the ninth goal: 
"Industries, innovation and infrastructure", in which the relevance of manufacturing for sustainable development is emphasized (UN 2015). This importance is highlighted by several researchers (Subramanian et al. 2014; Shubham et al. 2018; Toke and Kalpande 2018).

When focused on business context, the Corporate Social Responsibility concept stands out. It can be characterized as "the company's commitment to minimize or eliminate any damages and maximize it long-term beneficial impact on society" (Badurdeen and Jawahir 2017, p. 47). In a study performed by Nielsen (2013), it was concluded that $50 \%$ of clients interviewed accept higher prices for products and services when the companies are concerned with sustainable aspects. The development of manufacturing processes in according to Cleaner Production is an important requirement for companies to reach competitiveness and it has gaining an increasing importance (Ingarao et al. 2015; Kim et al. 2015; Singh and Madan 2016; Valase and Raut 2019). According to the definition proposed by UNEP (United Nations Environment Programme), Cleaner Production is "The continuous application of an integrated environmental strategy to processes, products and services to increase efficiency and reduce risks to humans and the environment" (UNEP 1990). In this sense, Cleaner Production can be an important ally of Industrial Ecology, which aims to understand "the circulation of materials and energy flows" (Saavedra et al. 2018, p. 1514). Both concepts are important to insert sustainability in industries and, consequently, consider environmental impacts from production to final disposal of the products.

Many factors motivate the development of sustainability in industries: increase of the raw materials prices; compliance with environmental laws; costumers requirements; concern with the environmental damages caused by the manufacturing; 
energy efficiency; and use of clean energy sources (Hauschild et al. 2005).

Sustainability, in its essence, is composed by three fundamental aspects: economic, environmental and social (Granatstein and Kupferman 2008). Through these pillars, companies can improve their industrial processes and consider impacts of the whole life cycle of their industrial operations, using tools such as Life Cycle Assessment (Bartocci Liboni and Oranges Cezarino 2014; Esquer et al. 2015).

When analysed the literature, the majority of the studies performed about sustainable manufacturing focus the machining processes. Processes as metal forming, casting, heat treatment, welding and electrostatic painting do not have the same emphasis attributed to the machining processes and, for this reason, we decided to study the five processes mentioned. The idea is to expand the debates related to sustainable manufacturing. Some considerations about the five manufacturing processes mentioned will be presented below.

According to Ingarao et al. (2011) and Li et al. (2017), the metal forming processes can be more sustainable through the analysis of following points: energy consumption, amount of material used in the process, emission of greenhouse gases generated by the energy source used, analysis of the sustainable lubricants, calculation of the appropriate temperature to perform the process, among other points. The study of the light materials conformation also should be considered in a sustainable perspective. The best conditions of the light materials conformability allow a better energy efficiency (Neugebauer et al. 2006).

The casting, a process widely used in the industry, has ample possibilities for sustainable improvements and it is a field few explored by academic research in a sustainable perspective. The impacts generated by the casting process occur in both environmental and social aspects. In the environmental aspect, the waste generated by 
the process can contaminate groundwater and soil (Krishnaraj 2015). From the social point of view, casting process can cause damage to the workers' health (Georgiadis and Kyrtopoulos 1999). Given the importance of casting process to the industry, it is necessary to define practices to minimize the impacts generated (Neto et al. 2009). The process of heat treatment also have been receiving few attention when considerate the sustainable perspective (de Souza et al. 2009). In a few hours, this process consume large amount of energy due to the high temperatures (Källén 2012). This high consume provides many opportunities for improvements towards sustainability. Modeling and simulation techniques are widely used to improve this process (de Souza et al. 2009). Other techniques that can be used to improve sustainable aspects are heat recovery, use of laser diodes and optimization of the furnace atmosphere (Berg 2014; Sonawane and Gunjal 2014; Arulrajah et al. 2017).

The electrostatic painting is a surface coating process more sophisticated than traditional processes. The electrostatic field forms between the part and the paint allow the process. There are many possibilities for improvement this process in a sustainable point of view. Poozesh et al. (2018) argues that there is a lot of waste in the process, since only $60 \%$ of the ink particles are attracted. According to Kellens et al. (2015), there are also improvements opportunities related to energy efficiency, reuse of water from cooling process and in ergonomic issues.

Finally, we present some considerations about welding process. According to Vimal et al. (2015), different sustainable practices are gaining more visibility in the process mentioned. A detailed analysis of the welding process allow to identify issues related to energy efficiency, environmental impacts (Sharma et al. 2015) and aspects related to operator health (Antonini 2003). 
In this mentioned context, this article aims to answer the following question: When focused the processes of metal forming, casting, electrostatic painting, heat treatment and welding, what are the main sustainable practices performed? We decided to use a systematic literature review for each process to reach the answer to the question.

Besides this introduction, there are has four other sections. Section 2 is composed by the theoretical background in which concepts related to sustainability and sustainable manufacturing are presented. Section 3 reports the methodological procedures used. Section 4 shows the results, synthetizing the main sustainable practices for each process studied. Finally, section 5 present the final conclusions about the research. References used are listed at the end.

\section{Theoretical Background}

\subsection{Sustainability and Sustainable Manufacturing}

The reconciliation between economic growth and sustainability is one of the main challenges experienced by companies nowadays. Sustainability, in its essence, is composed by three fundamental aspects (economic, environmental and social) and demands from organizations a greater commitment in the search for a better world (Granatstein and Kupferman 2008; Bartocci Liboni and Oranges Cezarino 2014). For Pusavec et al. (2010), the manufacturing sector can greatly contribute to the achievement of this last objective, since over the decades it has been one of those responsible for the excessive consumption of planet's resources and for the generation of wastes (Beekaroo et al. 2019).

Focusing specifically on the manufacturing sector, there is an increasingly interest of companies regarding sustainable practices that provide less resource use, 
lower energy consumption and, consequently, greater efficiency from the point of view of cleaner production (Rauch et al. 2015; Badurdeen and Jawahir 2017; Latif et al. 2017; Akbar and Irohara 2018). In fact, the concept of cleaner production is directly associated with sustainable manufacturing (Matos et al. 2018).

Haapala et al. (2013) and Rauch et al. (2015) argue that the interest of companies for sustainable issues is derived from the pressure exerted by society in recent decades and that significant progress has already been achieved. For Latif et al. (2017), the survival of manufacturing industry in the world in the coming decades will depend greatly on how it will continue to adopt the concepts of sustainability. Paul et al. (2014) highlight that the sustainable operations are an essential strategy for manufacturing companies.

To define sustainable manufacturing, it is necessary to define a priori the term manufacturing. Manufacturing is defined by the US government as "establishments engaged in the mechanical, physical, or chemical transformation of materials, substances, or components into new products” (U.S. Bureau of Labor Statistics 2019). Sustainable manufacturing, in its turn, may be defined as the development of processes and products with a lower negative impact on environment and society (Akbar and Irohara 2018). Indeed, Haapala et al. (2013), in their study, highlight this last point, arguing that sustainable manufacturing goes far beyond simply analyzing and modifying environmental performance. For these authors, sustainable manufacturing should be understood as a philosophy that seeks to integrate human, natural and ecological systems in the same way as possible in the same way as possible. Beekaroo et al. (2019) corroborate this point of view and argue that sustainable manufacturing must always perform as a process of continuous improvement. In this sense, for Moldavska and Welo (2019), the concepts of sustainable manufacturing can greatly 
contribute to the achievement of the 17 objectives defined by the UN in 2015 , especially in relation to those related to conscious production and consumption.

Badurdeen and Jawahir (2017) believe that sustainable manufacturing must encompass all stages of production, from product development to products' discard. For the same authors, the previous phases should always be analyzed critically in relation to reduction, reuse, recycling, recovery, redesign and remanufacturing. This position is corroborated by Paul et al. (2014) in their researches.

Haapala et al. (2013) stress that despite the advances made, many challenges and opportunities remain for manufacturing to become fully sustainable. These authors present challenges and opportunities in four categories: manufacturing processes and equipment, production systems, modifications in lifecycle patterns, and training of new professionals. Regarding the first category, the authors envision chances in creating new technologies and new knowledge that can further increase process efficiency and minimize negative impacts to workers, local and global communities. Regarding manufacturing systems, they argue the need to make concepts of sustainability go beyond the aspects of resource consumption, waste production and environmental impacts. For the authors, the question of sustainability must also be included in decision-making activities, such as planning and controlling production, selecting suppliers, etc. From the point of view of paradigm shifts, the authors suggest that sustainable manufacturing may require new business models with higher operating costs, due to the application of concepts such as reverse logistics, for example. This will require a thorough review of manufacturing concepts crystallized for many years. In terms of education, the training of new professionals should take into account the aspects of sustainable manufacturing and, for Haapala et al. (2013), not all professors are prepared for it. 
Analyzing academic literature, it is also possible to identify some difficulties related to implementation of sustainable practices in manufacturing processes. Examples of these difficulties are:

a) lack of interest of top management in relation to the implantation of sustainable techniques in the manufacturing processes (Mittal and Sangwan 2014): to obtain satisfactory results from sustainable techniques implementation, it is necessary dedication and persistent. Therefore, the support from top management is essencial;

b) difficulty in justifying investments related to sustainable issues (mainly in relation to the calculation of return on investments) (Bey et al. 2013): it is not always possible to clearly define when results can be achieved from a sustainable perspective, since there are many variables involved in the process, some of which are external to the company. Thus, the calculation of return on investments becomes more complex;

c) difficulty in adapting existing equipment from a technical point of view for sustainable purposes (Seliger 2007; Mittal and Sangwan 2014): it is common to see in the manufacturing park of many companies old equipment that does not allow adjustments for sustainability;

d) difficulty in correctly defining metrics to assess sustainable aspects (Mittal and Sangwan 2014; Rossi et al. 2016): measuring sustainability-related aspects often requires externalities analysis, making the definition of metrics complex;

e) lack of customer requirements for sustainability aspects (Bey et al. 2013; Rossi et al. 2016): although the concept of sustainability is widespread, 
many companies still do not value it; then, they do not place it as a requirement in their purchasing process.

Akbar and Irohara (2018) cite in their work Garetti and Taisch (2012) which point out to emerging research topics related to sustainable manufacturing. Examples of these topics include: discussions on new sustainable business models, efficient and sustainable organization of supply chains, new product development and life cycle analysis for sustainable gains, reduced use of scarce resources, more efficient use of energy in manufacturing processes, development of more efficient processes and new technologies, risk management associated with sustainability, ethics in manufacturing, among others.

Moldavska and Welo (2019) cite other research gaps in relation to the topic of sustainable manufacturing, such as the proposal of adequate indicators to measure industrial sustainability in general and not only with focus on environmental issues, models that allow an evaluation of sustainable manufacturing in a more scientific and less subjective way, ways of measuring the negative impacts generated by manufacturing in the social dimension, among others.

Through the above, it is possible to observe the importance of sustainability for the growth of the manufacturing sector and as there are still many research gaps plausible to be explored by the academic community. In literature review on sustainable practices applicable to the processes of metal forming, casting, electrostatic painting, heat treatment and welding, this article intends to contribute to the debate associated to the theme of sustainable manufacture. 


\subsection{Definition and characteristics of the manufacturing processes studied}

\subsubsection{Metal forming}

There are many ways to classify the metal forming processes. One of the most usual classifications is according to the predominant effort. Following this classification, there are the processes of (a) direct compression forming; (b) indirect compression forming;

(c) tensile conformation; (d) sher conformation; and (e) flexural conformation (Filho et al. 2011).

The metal forming processes are also evaluated according to the working temperature. The working temperature is considered cold when it is lower than the recrystallization temperature, otherwise hot work (Callister and Rethwisch 2009). According to Filho et al. (2011), the main metal forging processes are: rolling, extrusion, drawing, forging and stamping.

\subsubsection{Casting}

Currently there are many types of casting processes. They are differentiated by the type of material used in the mold (permanent or collapsible), by the pressure and by the force required to completely fill the mold. The processes of sand mold, lost wax, full mold and shell molding utilize disposable molds (they are performed once). The permanent molds are usually constructed in metal or graphite and allow the realization of several leaks (Ramaprasad and Srinivas 2012).

In the casting processes, it is necessary to create means to optimize the energy system to reduce cost and environment impacts. Energy savings can be made in two distinct but interconnected ways: directly with less fuel use, and indirectly, with lower consumption of raw material (Salonitis, Zeng, et al. 2016). 
Sand modeling is responsible for $70 \%$ of total castings performed in the world (Srinivasan et al. 2018). In this process, the mold is prepared with refractory material and it has a cavity with the desired final shape. The liquid metal is injected into the mold cavity, where it will solidify and form the part of interest. After cooling, the sand is removed and the final product is obtained (Kalpakjian 2013). Millions of tons of residual sand are generated in worldwide and this kind of product has a critical environmental impact (Singh and Siddique 2012). The correct destination of the residual sand is relevant for sustainability, since it is considered a hazardous waste (Yazoghli-Marzouk et al. 2014).

\subsubsection{Electrostatic painting}

According to the ISO 4618 standard, ink is a liquid or powder product which when applied to a substrate, forms an opaque film with decorative or particular protective characteristics. In its composition, there can be four groups of raw material: solvent, resin, pigments and additives, which can be chosen according to the environment that the piece will act and the material of this. Once the paint has been chosen, the form of application that can be with the brush, roller, air gun or electrostatic spray gun must be chosen.

The electrostatic painting has applications in several areas such as physics, chemistry, metallurgy and biology (Searson et al. 1999), being in the mechanical area one of the most economical forms due to the use of the paint. In this type of paint, duly prepared for its viscosity and other specifications, it is electrified in the pistol and projected in the part that is loaded with opposite load, in this way being attracted to the piece avoiding wastes (Bastos 2008). 


\subsubsection{Welding process}

According to Kou (2003, p. 3) the "fusion welding is a joining process that uses fusion of the base metal to make the weld". For this author, the three main kinds of fusion welding process are: "gas welding, arc welding and high-energy beam welding” and in the case of the arc welding, the most used process are: "shielded metal arc welding (SMAW), gas-tungsten arc welding (GTAW), plasma arc welding (PAW), gas-metal arc welding (GMAW), flux-cored arc welding (FCAW) [and] submerged arc welding (SAW)".

On the other hand, in a study carried out by the American Welding Society (Villaume 1979), more than 80 welding processes were identified, each of them having their own metallurgical and operational characteristics at the same time as they can represent potential risks for the health and safety of the welders. In this way, welders are not a uniform group, as these processes are operationalized under different circumstances (Antonini 2003).

According to Vimal et al. (2015), welding is a process with high possibilities of environmental damages, since it uses much energy in its operation. The fast manufacturing sector growth, especially in emerging countries, has generated global problems, such as high rates of natural resources use and greenhouse gas emissions (Sangwan 2011). Once in production activities welding is considered as the most important joining process, especially in steel constructions, (Chang et al., 2015), this issue becomes of special interest because of the impact it can generate in the environment and the health of workers.

\subsubsection{Heat Treatment process}

Heat treatment is a process in which a metal or alloy is exposed to heat over a 
determined period of time and then cooled in order to obtain the desired conditions or properties. Thus, heating as the sole end to hot work, as in forging, does not fit into this process (Dossett and Boyer 2005; Subject Guide Heat Treating 2015).

Among the applications of this process are the homogenization of molten metal alloys, the improvement of hot workability of the material, softening or hardening of metals, alteration of the workpiece microstructure and chemical alteration of surfaces (Subject Guide Heat Treating 2015).

Depending on the goal sought when performing this procedure, it gives rise to several processes, such as tempering, annealing, aging and stress relief. All of the different heat treatment processes consist of the following steps: 1) heating the material,

2) maintaining the temperature reached, 3) cooling at a controlled rate (Alberg 2003; Callister and Rethwisch 2009).

\section{Methodological Procedure}

The methodological procedure used to perform this research was a systematic literature review. According to Xavier et al. (2017) and Denyer and Tranfield (2009), in this methodology, researches regarding an issue are gathered, the contribution of them to the field are analysed, their data are compiled, and conclusions regarding the obtained results are drawn. For Leal et al. (2019), this methodology primarily aims to contribute to the literature by providing an overview of the state of art about an specific thematic and recognize gaps in the literature regarding this subject. Denyer and Tranfield (2009, p. 672) highlight that a systematic literature review must present a "replicable, scientific, and transparent approach", in order to reduce research bias. Hence, the establishment of a structured procedure is important to properly conduct a systematic literature review. This study uses a method based on Xavier et al. (2017), presented below. 
In this method, there are five steps to be followed: the identification of the research question, the definition of the procedure to perform the search, the selection of material to be used and the gathering of data from the material, data analysis and systematization, and results presentation and implications. The research question should be carefully elaborated in order to properly define the research's scope. In this research, the research question addressed was: "When focused the processes of metal forming, casting, electrostatic painting, heat treatment and welding, what are the main sustainable practices performed?". With this question, the authors delimited the scope of the study, in order to address a gap in the literature, since it was not found researches with similar objective. The second step is important to ensure the reliability and replicability of the research. In this step, the keywords as well as the databases used to conduct the search should be defined. The keywords used in this study were combinations of the terms: "sustainable manufacturing", "sustainable practices" "sustainability", "metal forming", “casting", "electrostatic painting", "heat treatment", and "welding”. Databases consulted were: Science Direct, Taylor and Francis, Emerald Insight, and Springer. Books were also used in this research and, when they provided an important contribution, theses were also used. In the third step, the material collected will be evaluated for researchers to decide whether these materials really fit their study. If materials used are articles, titles and abstracts should be used to perform this step. After this analysis, 70 references were used to elaborate the Tables from the results. Graphic 1 presents the publication years of these references. Through this graphic, it is possible to verify that the number of publications has been growing. The years 2014 and 2015 were presented the highest number of publications. Although sustainable manufacturing is not a new subject, the debates in the literature on this topic are growing and the year of 
publication of the 17 SDGs (2015) matches the phase in which there were more publications from the analysis, showing the contemporaneity of these two thematic.

Graphic 1. Publications years. Source: Authors.

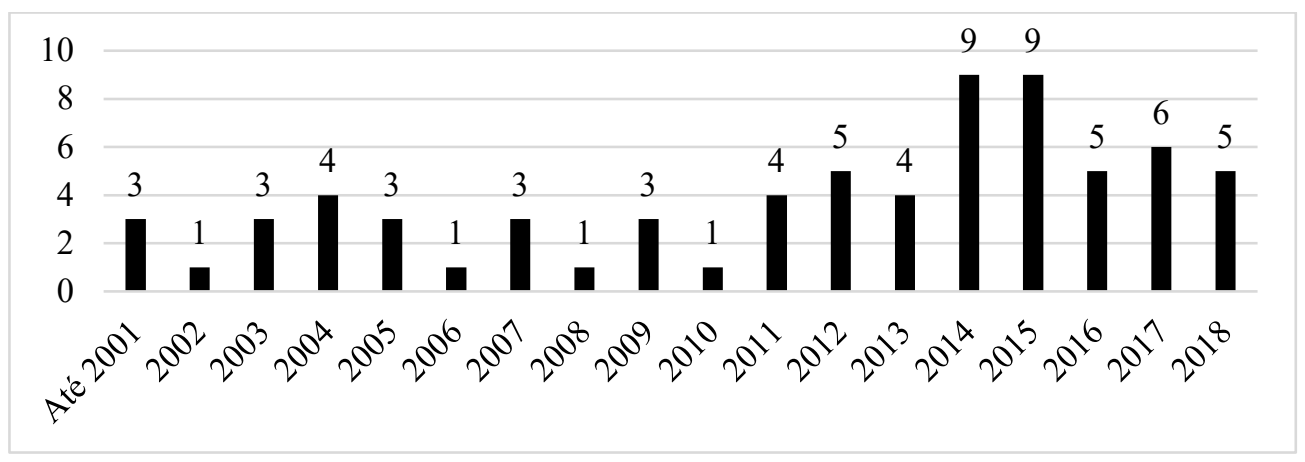

The fourth step is data analysis and systematization, performed in order to provide new knowledge from the information of previous studies. In this research, the sustainable practices of the analyzed processes are mapped and systematized in tables divided by processes kind, providing resources for manufacturing processes improvements towards sustainable development. The fifth step is basically characterized by the research dissemination, which is performed, in this case, by this article publication. The next section presents the results of this research.

\section{Results and Discussions}

This section is dedicated to present the results and the associated debates. Through systematic reviews of the literature, it was possible to structure Tables 1, 2, 3, 4 and 5 that synthesize the sustainable practices of each process. The first analysis performed is regarding sustainable practices of metal forming process, Table 1 presents the practices from the literature and the details are presented in the sequence. 
Table 1. Sustainable practices in metal forming process according to the literature (Source: vide table).

\begin{tabular}{|c|c|}
\hline Practices & References \\
\hline $\begin{array}{l}\text { Techniques for lubricants selection and } \\
\text { option to use ecological lubricants }\end{array}$ & $\begin{array}{l}\text { (Wang 2004; Bay et al. 2005; Ingarao et al. } \\
\text { 2011) }\end{array}$ \\
\hline $\begin{array}{l}\text { Incremental metal forming aiming the } \\
\text { sustainability }\end{array}$ & (Ingarao et al. 2012; Cooper et al. 2017) \\
\hline Use of blank customized & $\begin{array}{l}\text { (Kleiner et al. 2003; Ingarao et al. 2011; } \\
\text { Merklein et al. 2014; Han et al. 2018) }\end{array}$ \\
\hline Hydraulic metal forming & (Cooper et al. 2017) \\
\hline $\begin{array}{l}\text { Prolonging the use of matrix in metal } \\
\text { forming process }\end{array}$ & $\begin{array}{l}\text { (Walczyk and Hardt 1998; Haas et al. } \\
\text { 2002; Cooper et al. 2017) }\end{array}$ \\
\hline $\begin{array}{l}\text { Reuse of discarded materials in the } \\
\text { process }\end{array}$ & (Cooper et al. 2017) \\
\hline Servo press technology & (Osakada et al. 2011) \\
\hline Innovation in matrices and blanks formats & $\begin{array}{l}\text { (Shi et al. 2004; Parsa and Pournia 2007; } \\
\text { Azaouzi et al. 2011; Silva and Valente } \\
\text { 2012; Cooper et al. 2017) }\end{array}$ \\
\hline
\end{tabular}

One important aspect to be considered when study the sustainability in the metal forming process is the environmental impact of the lubricants used. Ingarao et al. (2011) argues that the lubricants used in the metal forming process should be selected considering aspects related to waste and cleaning. For Wang (2004), the use of volatile lubricants contributes to the reduction of the environmental impacts. It is important to note that the cost of lubricants in metal forming processes has traditionally been low. Therefore, this is a practice that can be easily adopted by any company.

The incremental metal forming is method that allows the molding of complex parts without the use of dedicated fixation systems, having a lower material expense, cost and process time, thus contributing to sustainability (Ingarao et al. 2012).

The use of blanks customized also contributes to sustainability, since they enable optimization of subsequent conformation processes (Merklein et al. 2014). The use of these methods allows to obtain semi-finished products and optimize the weight and load distribution of the components (Kleiner et al. 2003). In this way, there is a 
reduction of the waste and, in addition to material savings, the parts with smaller weights will have a lower cost of transportation and use leading to environmental gains (Ingarao et al. 2011).

The hydraulic metal forming is a process where a fluid is pressurized, shaping the metal against the matrix. The process stands out by allowing the conformation of several components, with different configurations, simultaneously. Using an arrangement with several molds and blanks, it is possible to be more efficient in terms of energy and productivity (Cooper et al. 2017).

For the manufacturing of small numbers of parts, the impact of the metal forming matrix in the environmental context is high, according to Cooper et al. (2017). The cost of the material and energy to produce the matrix is high, especially when it is considered the amount of parts produced, causing more environmental impact. To diminish the environmental negative impact, it is necessary to prolong the use of the matrix. An attractive method to surpass this challenge is the use of reconfigurable matrices (Haas et al. 2002).

During the manufacturing of the great among of parts, the material leftovers assume a prominent position considering environmental impacts (Cooper et al. 2017). This happens mainly during the process of blank cutting, where there are materials discarded. In this way, the material leftovers can be utilized to form smaller pieces, contributing to the sustainability.

In metal forming processes, the press efficiency depends of the energy maximization at the points of greatest need. Conventional presses use bigger motors and consequently consume more energy. Servo press technology allow a better control of the energy used generating a more efficient process (Osakada et al. 2011). 
Another point to emphasize in the servo press technology is the able of the servo motor to recover energy throughout deceleration. It can be stored in independents wheels and be reused in the following blows, contributing to energy efficiency (Osakada et al. 2011).

Faced the points present above, it is possible to note that innovation in metal forming matrices and blanks can contributed to the sustainable manufacturing (Cooper et al. 2017). The ideal blank geometry improves conformability, quality and also reduces material losses, which contributes to sustainable aspects (Azaouzi et al. 2011).

Table 2 presents the sustainable practices cited by the literature regarding to casting process. The explanation of these practices is presented following.

Table 2. Sustainable practices in casing process according to the literature (Source: vide table)

\begin{tabular}{|c|c|}
\hline Practices & References \\
\hline Quality control of the raw material & $\begin{array}{c}\text { (Lazzarin and Noro 2015; Salonitis, } \\
\text { Jolly, et al. 2016) }\end{array}$ \\
\hline $\begin{array}{c}\text { Studies to revise the environmental performance } \\
\text { of the furnaces used to melt the material }\end{array}$ & $\begin{array}{c}\text { (Matsuura and Fruehan 2009; Kipepe } \\
\text { and Pan 2015; Lazzarin and Noro } \\
\text { 2015; Salonitis, Jolly, et al. 2016) }\end{array}$ \\
\hline $\begin{array}{c}\text { Use of numerical programs to predict leakage } \\
\text { behavior, generating more optimized } \\
\text { production, lower energy loss, lower material } \\
\text { loss and higher quality of the final product, } \\
\text { themes totally related to environmental aspects }\end{array}$ & (Pagone et al. 2016) \\
\hline $\begin{array}{c}\text { Use of differentiated casting processes } \\
\text { process, such as casting sand }\end{array}$ & $\begin{array}{c}\text { (Hasanbeigi et al. 2014; Zeng et al. } \\
\text { 2014; Salonitis, Jolly, et al. 2016; } \\
\text { Salonitis, Zeng, et al. 2016; Salonitis } \\
\text { et al. 2017) }\end{array}$ \\
\hline $\begin{array}{c}\text { Recycling of waste generated by casting } \\
\text { procenghi- }\end{array}$ & $\begin{array}{c}\text { (Singh and Siddique 2012; Yazoghli- } \\
\text { Marzouk et al. 2014; Arulrajah et al. } \\
\text { 2017; Bhardwaj and Kumar 2017) }\end{array}$ \\
\hline
\end{tabular}

The first practice to be implemented in casing process aiming improvements on sustainability performance of the casting process is the analysis of the raw materials. The use of high-quality raw material reduces the waste of metal by oxidation and 
reduces the energy consumed. By reducing oxidation, it is also possible to increase the melt speed (Salonitis, Zeng, et al. 2016) and reduce the total process time (Lazzarin and Noro 2015).

The process of metal melting consumes $30 \%$ of the energy used in casting process (Salonitis, Zeng, et al. 2016). Thus, many improvement opportunities related to cleaner production can be identified, e.g. optimizing of the energy consumption in this phase can reduce the environmental impact. The design of furnaces with appropriate size can prevent considerable waste (Salonitis, Zeng, et al. 2016). The use of the ceramics' lids and minimization the opening of the furnace lid are characterized as good practices (Lazzarin and Noro 2015). In comparison to other types of furnaces, the induction furnace is more efficient (Salonitis, Zeng, et al. 2016). It is possible to observe that many companies still use obsolete furnaces with low energy efficiency and can be considered an opportunity for improvements.

The use of computer numerical programs makes possible to predict the behavior of the fluid in the leak, thus generating optimized conditions. If conditions are optimized, less material and less energy are consumed, providing environmental gains (Pagone et al. 2016).

The use of different casting processes also can be presented as sustainable alternatives. There are many processes in the literature, but two weel-known processes are cited here: CRIMSON and COREX. The use of the CRIMSON process results in better casting quality, while increase productivity with less investment (Salonitis, Zeng, et al. 2016). COREX process also allows the production with less expense and in a sustainable way (Hasanbeigi et al. 2014).

At last, it worth to highlight the recycling of waste generated by the casting process. Some types of castings process use sand in the molding phase (Arulrajah et al. 
2017). If correctly recycled, the sand can be used in the concrete production as an alternative to the use of the natural sand, leading to environmental gains (Singh and Siddique 2012; Bhardwaj and Kumar 2017). In addition, the recycled sand can be widely used in civil engineering applications, such as construction of roads, constriction of barrier, fabrication of brick blocks, and others (Yazoghli-Marzouk et al. 2014; Bhardwaj and Kumar 2017). These applications are directly associated with the life cycle analysis of casting processes and meet the concepts of reuse of production process waste disseminated by Cleaner Production.

Table 3 presents the sustainable practices cited by the literature regarding to electrostatic painting. The explanation of these practices is presented following.

Table 3. Sustainable practices in electrostatic painting process according to the literature (Source: vide table)

\begin{tabular}{|c|c|}
\hline Practices & References \\
\hline $\begin{array}{l}\text { Use capacitors to correct the power factor of } \\
\text { the equipment }\end{array}$ & (Choi et al. 2015) \\
\hline $\begin{array}{l}\text { Add catalysts to the ink to facilitate } \\
\text { atomization and energization }\end{array}$ & (Sowinski and Mehrani 2015) \\
\hline $\begin{array}{l}\text { Use paints that have been produced with } \\
\text { waste from other processes }\end{array}$ & (Pavlovich et al. 2004) \\
\hline $\begin{array}{l}\text { Use equipment such as ionized air to remove } \\
\text { any remaining particles in the air or to clean } \\
\text { the part }\end{array}$ & (Yosri 2018) \\
\hline $\begin{array}{c}\text { Equipment with hydrodynamic application } \\
\text { systems. }\end{array}$ & (Kluczek 2014) \\
\hline $\begin{array}{l}\text { Reuse water from pre-treatments or cooling } \\
\text { systems after curing the paint }\end{array}$ & $\begin{array}{l}\text { (Kellens et al. 2015; Boer and Blaga } \\
\text { 2016) }\end{array}$ \\
\hline $\begin{array}{l}\text { If painting is done with liquid paint, use } \\
\text { water as a solvent }\end{array}$ & $\begin{array}{l}\text { (Wang and Chen 1993; Bjørg et al. } \\
\text { 2004) }\end{array}$ \\
\hline Better use of heat from the oven & (Roberts and Roberts 1976) \\
\hline $\begin{array}{l}\text { Environmental filtering and / or ventilation } \\
\text { systems }\end{array}$ & (Blomqvist et al. 2005; Kluczek 2014) \\
\hline
\end{tabular}

The first sustainable practice from Table 3 refers to the equipment used in electrostatic painting, which consumes inductive power with high voltage. Thus, to reduce consumption, capacitors are inserted into the system as a way to increase the 
power factor and reduce the total electric consumption, generating sustainable gains to the process (Choi et al. 2015).

The following practice is related to the composition of the paint aiming for greater ease during its application in the piece. For this, most pressurized nitrogen is injected, which allows more energization and better coverage, thus reducing waste (Sowinski and Mehrani 2015).

Regarding the ink used, it is possible to think of the R's policy, with the R to recycle using waste from other processes for manufacturing the same. Pavlovich et al. (2004) portrays in his work the use of coke processing residues and coal industries in the production of anticorrosive paints and varnishes with a durability of 2 to 3 times longer than conventional inks. In this sense, there are many possibilities in the development of new ink formulas to enable greater environmental gains.

Considering the existence of remaining particles on the material, it is recommended to apply methods to remove them and make the air cleaner, thus enhancing the quality of the work environment (Yosri 2018) propose the use of ionized air in the electrostatic painting both for the removal of said particles and for the cleaning of the part. According to this author, improving the quality of the air reduces the possibilities of occupational diseases, meeting the requirements mentioned by OHSAS 18001 and ISO 45001 (BSI 2007; ISO 2018).

The fifth practice relates to processes that use liquid paint. Kluczek (2014) advises the use of airless hydrodynamic applicators so that the consumption of the cover material is lower, since in conventional gun application the high-pressure mixture mixes with air currents and proportional greater wastage. This type of applicator also allows the use of more sustainable paints. 
In relation to the process, one can think of the " $\mathrm{R}$ " of reusing the process water. Water is characterized as a very important component from the pretreatment of the part to the cooling. (Kellens et al. 2015) advise to implement a system reuse of process water, aiming at lower consumption of this resource. (Boer and Blaga 2016), in their study, present a plant that allows the use of a system to treat water with waste efficiently, thus generating less environmental impacts.

Regarding the composition of liquid paints, another much debated topic is related to the use of solvents. Solvents, in general, generate a large environmental passive. Wang and Chen (1993) and Bjørg et al. (2004) advocate the use of water as a solvent instead of organic solvents, because although it is more volatile and depends on environmental conditions, the latter emits volatile organic components (VOC) that can cause serious problems for operators.

Also, in relation to the electrostatic painting process, practices can be applied to reuse the heat generated, achieving greater energy efficiency. Roberts and Roberts (1976) suggests heating the furnace from the heat flux generated in some other reaction, thereby reducing energy consumption and improving environmental performance.

The last practice refers to the use of filters that make it possible to collect as much particles as possible and thus improve air quality in the work area. Once again, this practice meets ISO 45001 and OHSAS 18001 (BSI 2007; ISO 2018). Kluczek (2014) presents in his work a filtration system that allowed the reuse of the captured particles, generating sustainable gains. Blomqvist et al. (2005), in addition, propose a ventilation system in the application so that air is renewed, and organic particulates are not inhaled by the operators.

Table 4 presents the sustainable practices cited by the literature regarding to electric welding process. The explanation of these practices is presented following. 
Table 4. Sustainable practices in electric welding process according to the literature (Source: vide table).

\begin{tabular}{|c|c|}
\hline Practices & References \\
\hline $\begin{array}{c}\text { Application of protective measures to reduce } \\
\text { the impact on operator health }\end{array}$ & (Antonini 2003) \\
\hline $\begin{array}{c}\text { Implementation of methodologies that seek the } \\
\text { analysis of environmental impacts }\end{array}$ & $\begin{array}{c}\text { (Seliger 2007; Mittal and Sangwan } \\
\text { 2014; Chang et al. 2015) }\end{array}$ \\
\hline $\begin{array}{c}\text { Use of automated processes for welding } \\
\text { (Seliger 2007; Mittal and Sangwan } \\
\text { 2014; Liu et al. 2014) }\end{array}$ \\
\hline $\begin{array}{c}\text { Use of welding wires that reduce the rate of } \\
\text { smoke generation (coated with nano-alumina } \\
\text { or similar technology) }\end{array}$ & (Sivapirakasam et al. 2015) \\
\hline $\begin{array}{c}\text { Critical analysis regarding the possibilities of } \\
\text { replacing the current welding process with } \\
\text { another one with better sustainable } \\
\text { performance }\end{array}$ & (Gharma et al. 2015) \\
\hline $\begin{array}{c}\text { Control and minimization of energy } \\
\text { consumption in the welding process }\end{array}$ & \begin{tabular}{c} 
(Gialos) \\
\hline
\end{tabular}
\end{tabular}

In Table 4, the first practice listed is related to employees. There are researches showing the relationship between welders work some type of diseases. Therefore, a greater attention is needed to several factors. Antonini (2003) cites some factors that may be detrimental to operators' health, such as exposure to high temperatures, presence of smoke in the operator's breathing zone, exposure to high noise, exposure to radiation and inhalation of nano particles and / or chemical gases, among others. In this sense, it is important to highlight the social aspect of sustainability, related to better operators' quality of life.

The use of management tools such as the Life Cycle Assessment can be very useful in a sustainability perspective by indicating the impact processes such as welding can have on the environment and society. When compared with other automatic welding processes, for example, the manual welding process consumes a greater amount of resources and energy, as well as posing a much greater potential risk to welders' health (Chang et al. 2015). 
In the same line of reasoning described in the previous paragraph, it is noticed that the automatic machines are programmed to always weld in the correct size and length, reducing the energy consumption and increasing the productivity. Manual welding, in turn, can lead to larger welds, generating waste in terms of time and resources. Moreover, as already mentioned, manual welding involves several risks to the operator's health (Seliger 2007).

Gas reduction in the welding process is a practice that has contributed to the operator's health and to minimizing environmental impacts (Sivapirakasam et al. 2015) cite a new method for reducing welding fumes at source. This method involves immersing a solder wire prior to its flow coating into a solution containing aluminum isopropoxide to obtain a thin film, that reduce the smoke concentration by up to $62 \%$, contributing to environment aspects.

To improve performance in terms of welding process sustainability, Gialos et al. (2018) recommends that the processes be always compared to the four criteria: a) weight and geometry of the part, b) processing time or solder application, c) cost, and d) gas emissions. It can be noted that the recommendations of Gialos et al. (2018) are in accordance with the concept of Triple Bottom Line.

Finally, we highlight the study of Sharma et al. (2015) that advocates regarding the control and minimization of the use of energy in the welding process. For the aforementioned author, minimizing energy consumption is part of the so-called Environmentally Conscious Manufacturing and can greatly contribute to sustainability.

Table 5 presents the sustainable practices cited by the literature regarding to heat treatment process. The explanation of these practices is presented following. 
Table 5. Sustainable practices in heat treatment process according to the literature (Source: vide table)

\begin{tabular}{|c|c|}
\hline Practices & References \\
\hline $\begin{array}{l}\text { Mapping of energy consumption in the } \\
\text { heat treatment process }\end{array}$ & (Källén 2012; Berg 2014) \\
\hline $\begin{array}{l}\text { Measures such as the use of economical } \\
\text { light bulbs, the insulation of the main oven } \\
\text { doors, leakage checking in the compressed } \\
\text { air system, dampers in the preheating } \\
\text { furnace, equipment shutdown during } \\
\text { weekends, among others }\end{array}$ & (Källén 2012) \\
\hline Use of method for heat recovery & $\begin{array}{l}\text { (Mehta 2011; Källén 2012; Berg 2014; } \\
\text { Schönfelder et al. 2016; Diop et al. 2017) }\end{array}$ \\
\hline $\begin{array}{c}\text { Simulation tools or software to increase } \\
\text { process efficiency }\end{array}$ & $\begin{array}{c}\text { (Alberg 2003; Yang et al. 2007; } \\
\text { Elmabrouk and Wu 2012; Lenz and Pfeifer } \\
\text { 2013; Mendikoa et al. 2013; Steinboeck et } \\
\text { al. 2013; Bobkov et al. 2015; Velichkin } \\
\text { and Zavyalov 2018; Baykasoğlu and } \\
\text { Ozsoydan 2018) }\end{array}$ \\
\hline $\begin{array}{l}\text { Laser-assisted thermal treatment making } \\
\text { sustainable gains possible }\end{array}$ & $\begin{array}{c}\text { (Haake and Zediker 2005; Bonss et al. } \\
\text { 2009; Balasubramanian et al. 2014) }\end{array}$ \\
\hline $\begin{array}{c}\text { Control of the composition of the heating } \\
\text { atmosphere in the case of natural gas-fired } \\
\text { ovens }\end{array}$ & (Stupnišek 2010; Schmitz et al. 2017) \\
\hline $\begin{array}{c}\text { Use of organic oils for tempering and } \\
\text { correct disposal }\end{array}$ & $\begin{array}{c}\text { (Dean and Sahay 2008; de Souza et al. } \\
\text { 2009) }\end{array}$ \\
\hline $\begin{array}{c}\text { Accident prevention measures in case of } \\
\text { exposure to toxic gases such as ammonia } \\
\text { or monoxide }\end{array}$ & $\begin{array}{c}\text { (Stanescu and Stratton 2006; Safety in heat } \\
\text { treatment 2013) }\end{array}$ \\
\hline $\begin{array}{c}\text { Preventive measures against fires or } \\
\text { explosions caused by ovens, used gases or } \\
\text { by quenching oil }\end{array}$ & $\begin{array}{c}\text { (Stanescu and Stratton 2006; Safety in heat } \\
\text { treatment 2013) }\end{array}$ \\
\hline
\end{tabular}

According to the first practice mentioned in Table 5, energy consumption should be an object of analysis for sustainability purposes. Given the large amount of energy that the heat treatment process uses, the reduction of this resource and the minimization of carbon dioxide emissions become essential (Berg 2014). According Källén (2012), mapping manufacturing processes that consume more energy can contribute greatly to reducing environmental impacts. According to a study carried out by the same author, $7.7 \%$ of the electricity used in a large industrial heat treatment plant can be saved per year if some measures are taken. Investments such as using more economical light 
bulbs, insulating furnace doors, turning off equipment during weekends, and others have proved profitable and also contribute to the goals of cleaner production.

Residual heat recovery is also characterized as an important practice for increasing the energy efficiency of a furnace. Energy from gases at high temperatures, which can reach $65 \%$ of the total input energy, can be used in other stages, such as preheating aluminum billets or even replacing natural gas as an energy source (Mehta 2011; Berg 2014; Diop et al. 2017).

One way of reducing cost and time in the development of products related to heat treatment processes and, consequently, contributing to sustainability is characterized using simulation tools. Simulation tools can be characterized as an important ally in the search for sustainability. This technology allows to obtain a prediction of the properties and final form of the component submitted to the process, generating more control and less waste of time and resources (Alberg 2003).

Bonss et al. (2009, p. 219) mention that "Laser surface hardening is a heat treatment process for steel and grey cast iron". In this process, there is no use of water or oil as a cooling media, since the method is extinguishable on its own, since the heat flow is directed to the rest of the cold material. Laser hardening has some advantages, for example, the absence of heating time as in conventional furnaces, high energy efficiency of the light beam, since the energy is released directly into the steel with no losses in the exhaust gases. Another factor is that, unlike conventional ovens that must be kept at high temperatures during shutdowns, the laser's ignition energy is close to zero. All this leads to a high energy efficiency and, consequently, lower environmental impact (Balasubramanian et al. 2014).

In the heat treatment, during heating of parts inside the furnace, different types of gaseous atmospheres are used in order to protect them from oxidation. These 
atmospheres, however, emit compounds harmful to the environment such as carbon dioxide and oxides of nitrogen, aggravated when there is no complete burning of the gas. Thus, measures to control the composition of this atmosphere or even the use of inert gases are practices already applied for a more sustainable production (Stupnišek 2010; Schmitz et al. 2017).

According to Dean and Sahay $(2008$, p. 1), "petroleum-based mineral oil is a commonly used quenching media for heat treatment", since it offers a moderate cooling rate, reducing the distortions of the parts subjected to the process. However, this oil is linked to various environmental, health and safety problems such as the inhalation of smoke generated, emission of greenhouse gases, fire risks, oil spills and contamination of the groundwater. Therefore, the use of mineral oil for this purpose is being discouraged and sustainable alternatives have been developed, such as vegetable oils based on canola, soybean, starch, sunflower seed, corn, among others, or even synthetic organic polymers (Dean and Sahay 2008; de Souza et al. 2009). In this sense, the authors of this article point out that there are many possibilities for research in this area.

All manufacturing processes have associated risks, however in thermal treatment facilities the existing hazards may be greater. (Stanescu and Stratton 2006; Safety in heat treatment 2013) cite some of these risks:

a) Exposure to toxic gases such as ammonia and carbon monoxide is quite dangerous with the potential to kill. Measures for evacuation of the exposed area and disposal of the contaminant are very important in cases of leakage.

b) Contact with high temperature objects or surfaces or even with flames can be prevented with the proper use of personal protective equipment. 
c) Fires or explosions can easily be generated in installations of this type, so fire-fighting systems are indispensable.

In short, accidents can always be avoided with the cooperation and awareness of all using properly the protective equipment and following the existing procedures in the factory.

In general, when analyzing all the practices mentioned above, it can be observed that there is a great emphasis on reducing energy consumption or reducing inputs. However, there are many other possibilities for processes to gain even more from sustainability perspective (Ingarao et al. 2015), especially considering the concepts of Cleaner Production and Industrial Ecology.

This opens up many possibilities for research and development, both in the technical aspect of manufacturing engineering related to each of the processes and in relation to production management aspects. Among the managerial aspects, we highlight, for example, the development of methods to facilitate the measurement of return on investments related to the adoption of sustainable practices in manufacturing processes, also considering externalities. This would provide less uncertainty for entrepreneurs and could boost investments in sustainable manufacturing. The authors of this article also believe that government actions could greatly contribute to stimulating the adoption of sustainable practices in industrial processes.

\section{Conclusions}

The main objective of this research was to list sustainable practices in the processes of metal forming, casting, electrostatic painting, heat treatment and welding. Observing the results found, it is possible to affirm that the objective was reached. We emphasize again that the manufacturing processes mentioned are few explored by literature regarding to sustainable aspects. More emphasis is designated to de machining 
processes when considered sustainable practices. The listing of practices presented in Section 4 can contribute to future academic researches and help professionals of companies to improve manufacturing processes.

Many practices are possible to be applied in each process, as demonstrated, but in most of them issues related to the better use of materials and energy efficiency are highlighted. In fact, the aspects mentioned are highlighted as important metrics to be achieved in sustainable manufacturing according to Ingarao et al. (2015).

The main limitation of this research is the fact that it was done based on information from articles available in some scientific databases. The use of other articles available in different bases may lead to the identification of other sustainable practices. It should be emphasized, however, that this limitation does not detract the quality of the results presented. The authors of this article understand that sustainability practices in processes of metal forming, casting, heat treatment, welding and electrostatic painting is a theme few explored and deserve greater attention of the academic community. The exploratory results present here are an important way to widen the debate.

Finally, as a proposition of future study, we suggest to use the mentioned sustainable practices to carry out a survey with professionals that work in manufacturing companies, in order to identify how much they are applied in the manufacturing context.

\section{Acknowledgements}

To be inserted

\section{References}

Akbar M, Irohara T. 2018. Scheduling for sustainable manufacturing : A review. J Clean Prod. 205:866-883. 
Alberg H. 2003. Material Modelling for Simulation of heat treatment. [place unknown]: Luleå University of Technology.

Antonini JM. 2003. Health Effects of Welding. Crit Rev Toxicol. 33(1):61-103. Available from: http://www.tandfonline.com/doi/full/10.1080/713611032

Arulrajah A, Yaghoubi E, Imteaz M, Horpibulsuk S. 2017. Recycled waste foundry sand as a sustainable subgrade fill and pipe-bedding construction material: Engineering and environmental evaluation. Sustain Cities Soc. 28:343-349.

Azaouzi M, Belouettar S, Rauchs G. 2011. A numerical method for the optimal blank shape design. Mater Des. 32(2):756-765.

Badurdeen F, Jawahir IS. 2017. Strategies for Value Creation Through Sustainable Manufacturing. Procedia Manuf. 8(October 2016):20-27.

Balasubramanian S, Manonmani K, Hemalatha RM. 2014. Lasers in Green Manufacturing Processes. Appl Mech Mater. 592-594:473-478.

Bartocci Liboni L, Oranges Cezarino L. 2014. Strategy for sustainability in a Brazilian sugarcane industry. World J Entrep Manag Sustain Dev. 10(1):2-12.

Bastos C de O. 2008. Estudo comparativo das propriedades dos revestimentos obtidos pela aplicação de tintas líquidas e a pó em peças metálicas em sistemas de pintura eletrostática. [place unknown]: Master Thesis, Instituto de Pesquisas Tecnológicas IPT.

Bay NO, Olsson D, Andreasen JL. 2005. Testing of environmentally friendly lubricants for sheet metal forming. In: 8th Int Conf Technol Plast. [place unknown].

Baykasoğlu A, Ozsoydan FB. 2018. Dynamic scheduling of parallel heat treatment furnaces: A case study at a manufacturing system. J Manuf Syst. 46:152-162. Available from: https://linkinghub.elsevier.com/retrieve/pii/S0278612517301619

Beekaroo D, Callychurn DS, Hurreeram DK. 2019. Developing a sustainability index for Mauritian manufacturing companies. Ecol Indic. 96(March 2017):250-257. Available from: https://doi.org/10.1016/j.ecolind.2018.09.003

Berg P. 2014. Energy management in heat treatment. [place unknown]: Department of Energy and Environment Division of Heat and Power Technology, Chalmers University 
of Technology.

Bey N, Hauschild MZ, McAloone TC. 2013. Drivers and barriers for implementation of environmental strategies in manufacturing companies. CIRP Ann - Manuf Technol. 62(1):43-46. Available from: http://dx.doi.org/10.1016/j.cirp.2013.03.001

Bhardwaj B, Kumar P. 2017. Waste foundry sand in concrete: A review. Constr Build Mater. 156:661-674.

Bjørg Æ, Hollund E, Moen ÆBE. 2004. Reduced exposure to organic solvents by use of water-based paint systems in car repair shops. Int Arch Occup Env Heal.:31-38.

Blomqvist A, Düzakin-Nystedt M, Ohlson C-G, Andersson L, Jönsson B, Nielsen J, Welinder H. 2005. Airways symptoms, immunological response and exposure in powder painting. Int Arch Occup Environ Health. 78(2):123-131. Available from: http://link.springer.com/10.1007/s00420-004-0573-7

Bobkov VI, Borisov V V., Dli MI, Meshalkin VP. 2015. Multicriterial optimization of the energy efficiency of the thermal preparation of raw materials. Theor Found Chem Eng. 49(6):842-846.

Boer J, Blaga P. 2016. Optimizing Production Costs by Redesigning the Treatment Process of the Industrial Waste Water. Procedia Technol. 22:419-424. Available from: https://linkinghub.elsevier.com/retrieve/pii/S2212017316000724

Bonss S, Seifert M, Brenner B, Beyer E. 2009. Laser beam hardening - Energy efficient heat treatment? In: Int Congr Appl Lasers Electro-Optics. [place unknown]: Laser Institute of America; p. 219-224. Available from: http://aip.scitation.org/doi/abs/10.2351/1.5061556

Brundtland GH. 1987. Report of the World Commission on Environment and Development: Our Common Future. Oslo.

BSI. 2007. OHSAS 18001 - Occupational Health and Safety.

Callister W, Rethwisch D. 2009. Materials Science and Engineering: An Introduction. Hoboken, NJ, USA: John Wiley \& Sons.

Chang Y, Sproesser G, Neugebauer S, Wolf K, Scheumann R, Pittner A, Rethmeier M, Finkbeiner M. 2015. Environmental and Social Life Cycle Assessment of welding 
technologies. Procedia CIRP. 26:293-298.

Choi J, Hyon BJ, Kim J, Park JS. 2015. Development of Single Phase PFC Module for Electrostatic Coating Machine Applications. 10th Conf Ind Electron Appl.:1751-1754.

Cooper DR, Rossie KE, Gutowski TG. 2017. Journal of Materials Processing Technology The energy requirements and environmental impacts of sheet metal forming : An analysis of five forming processes. J Mater Process Tech. 244:116-135.

Dean SW, Sahay SS. 2008. Starch-Based Quenchants as an Eco-Friendly Alternative to Quenching Oil. J ASTM Int. 5(10):101789. Available from: http://www.astm.org/doiLink.cgi?JAI101789

Denyer D, Tranfield D. 2009. Producing a systematic review. In: Buchanan DA, Bryman A, editors. Sage Handb Organ Res methods. Thousand Oaks: SAGE Publications Ltd; p. 671-689. Available from: http://www.tandfonline.com/doi/full/10.1080/03079451003781858

Diop MA, Xiaomeng C, Hassan MI. 2017. Billets Heat Treatment using Flue Gas for Energy Efficiency and Batching Cycle Time Reduction. Energy Procedia. 105:33773383.

Dossett JL, Boyer HE. 2005. ASM International staff who worked on this project include Scott Henry, Senior Product Manager; Bonnie Sanders, Manager of Production; Madrid Tramble, Senior Production Coordinator. [place unknown]: Production Assistant.

Elmabrouk EM, Wu Y. 2012. Enhancing the heat transfer in a heat treatment furnace through improving the combustion process in the radiation tubes. IMA J Appl Math (Institute Math Its Appl. 77(1):59-71.

Esquer J, Vaeza-Gastélum C, Remmen A, Alvarez-Chávez CR, Velázquez LE. 2015. Life cycle assessment for printed newspapers in Northwestern Mexico. Int J Sustain Dev World Ecol. 22(3):259-268. Available from: http://dx.doi.org/10.1080/13504509.2015.1020456 Filho EB, Zavaglia CAC, Button ST, Gomes E, Nery FAC. 2011. Conformação Plástica dos Metais. [place unknown].

Garetti M, Taisch M. 2012. The Management of Operations Sustainable manufacturing: 
trends and research challenges Sustainable manufacturing : trends and research challenges. 7287.

Georgiadis P, Kyrtopoulos SA. 1999. Molecular epidemiological approaches to the study of the genotoxic effects of urban air pollution. Fundemental Mol Mech Mutagen. 428:91-98.

Gialos AA, Zeimpekis V, Alexopoulos ND, Kashaev N, Riekehr S, Karanika A. 2018. Investigating the impact of sustainability in the production of aeronautical subscale components. J Clean Prod. 176:785-799.

Granatstein D, Kupferman E. 2008. Sustainable horticulture in fruit production. Acta Hortic. 767:295-308.

Haake J, Zediker M. 2005. Heat Treating and Cladding Operations with High-Power Diode Lasers. In: Photonics West 2005. San Jose.

Haapala KR, Camelio J, Sutherland JW, Skerlos SJ, Dornfeld DA. 2013. A Review of Engineering Research in Sustainable Manufacturing. 135(August 2013):1-16.

Haas E, Schwarz RC, Papazian JM. 2002. Design and test of a reconfigurable forming die. J Manuf Process. 4(1):77-85.

Han S, Hwang T, Oh I, Choi M, Moon YH. 2018. Manufacturing of tailor-rolled blanks with thickness variations in both the longitudinal and latitudinal directions. J Mater Process Technol. 256(February):172-182.

Hasanbeigi A, Arens M, Price L. 2014. Alternative emerging ironmaking technologies for energy-efficiency and carbon dioxide emissions reduction: A technical review. Renew Sustain Energy Rev. 33:645-658.

Hauschild M, Jeswiet J, Alting L. 2005. From Life Cycle Assessment to Sustainable Production: Status and Perspectives. CIRP Ann - Manuf Technol. 54(2):1-21.

Ingarao G, Ambrogio G, Gagliardi F, Di Lorenzo R. 2012. A sustainability point of view on sheet metal forming operations: Material wasting and energy consumption in incremental forming and stamping processes. J Clean Prod. 29-30:255-268.

Ingarao G, Lorenzo R Di, Micari F. 2011. Sustainability issues in sheet metal forming processes : an overview. J Clean Prod. 19(4):337-347. 
Ingarao G, Priarone PC, Gagliardi F, Di Lorenzo R, Settineri L. 2015. Subtractive versus mass conserving metal shaping technologies: An environmental impact comparison. J Clean Prod. 87(C):862-873.

ISO. 2018. ISO 45001 - Occupational health and safety.

Källén M. 2012. Energy Efficiency Opportunities within the Heat Treatment Industry. [place unknown]: Master Thesis, Chalmers University of Technology.

Kalpakjian S. 2013. Manufacturing Manufacturing Engineering and Technology. [place unknown].

Kellens K, Paraskevas D, Dewulf W, Duflou J. 2015. Environmental comparison of metal coating processes. Procedia CIRP. 29:420-425.

Kim DB, Shin SJ, Shao G, Brodsky A. 2015. A decision-guidance framework for sustainability performance analysis of manufacturing processes. Int J Adv Manuf Technol. 78(9-12):1455-1471.

Kipepe TM, Pan X. 2015. Energy improvement in induction furnace using foaming slag with variation of carbon injection. J Energy South Africa. 26(2):64-73.

Kleiner M, Geiger M, Klaus A. 2003. Manufacturing of lightweight components by metal forming. CIRP Ann - Manuf Technol. 52(2):521-542.

Kluczek A. 2014. Application of best available techniques in an enterprise producing heating devices. J Clean Prod. 83:444-453.

Kou S. 2003. Welding metallurgy. Hoboken, NJ, USA: John Wiley \& Sons, Inc.

Krishnaraj R. 2015. Foundry Air Pollution: Hazards, Measurements and Control. In:

Lichtfouse E, Schwarzbauer J, Robert D, editors. CO2 Sequestration, Biofuels Depollut.

Vol. 5. Cham: Springer International Publishing; p. 335-357. Available from:

http://link.springer.com/10.1007/978-3-319-11906-9

Latif HH, Gopalakrishnan B, Nimbarte A, Currie K. 2017. Sustainability index development for manufacturing industry. Sustain Energy Technol Assessments. 24:8295.

Lazzarin RM, Noro M. 2015. Energy efficiency opportunities in the production process of cast iron foundries: An experience in Italy. Appl Therm Eng. 90:509-520. 
Leal GSS, Guedria W, Panetto H. 2019. Interoperability assessment: A systematic literature review. Comput Ind. 106:111-132. Available from:

https://doi.org/10.1016/j.compind.2019.01.002

Lenz W, Pfeifer H. 2013. Berechnung von thermospannungen in w??rmebehandlungsanlagen mittels gekoppelter numerischer verfahren. ChemieIngenieur-Technik. 85(8):1312-1316.

Li Y, Chen X, Liu Z, Sun J, Li F, Li J, Zhao G. 2017. A review on the recent development of incremental sheet-forming process. Int J Adv Manuf Technol. 92(58):2439-2462. Available from: http://link.springer.com/10.1007/s00170-017-0251-z

Liu Y, Shao Z, Zhang Y, Fu B, Yang R. 2014. Virtualized welding based teleoperation with pipe gas tungsten arc welding applications. In: 2014 IEEE/ASME Int Conf Adv Intell Mechatronics. [place unknown]: IEEE; p. 1604-1609. Available from: http://ieeexplore.ieee.org/lpdocs/epic03/wrapper.htm?arnumber=6878313

Matos LM, Anholon R, da Silva D, Cooper Ordoñez RE, Gonçalves Quelhas OL, Filho WL, de Santa-Eulalia LA. 2018. Implementation of cleaner production: A ten-year retrospective on benefits and difficulties found. J Clean Prod. 187:409-420. Available from: https://linkinghub.elsevier.com/retrieve/pii/S0959652618308527

Matsuura H, Fruehan RJ. 2009. Slag Foaming in an Electric Arc Furnace. ISIJ Int. 49(10):1530-1535.

Mehta DP. 2011. Energy Efficiency through Waste Heat Recovery in Automotive Manufacturing Related Industries. In: SAE 2011 World Congr Exhib. [place unknown]. Available from: http://papers.sae.org/2011-01-0327/

Mendikoa I, Sorli M, Armijo A, Garcia L, Erausquin L, Insunza M, Bilbao J, Friden H, Björk A, Bergfors L, et al. 2013. Energy Efficiency Optimisation in Heat Treatment Process Design. [place unknown].

Merklein M, Johannes M, Lechner M, Kuppert A. 2014. A review on tailored blanks Production, applications and evaluation. J Mater Process Technol. 214(2):151-164.

Mittal VK, Sangwan KS. 2014. Development of a structural model of environmentally conscious manufacturing drivers. J Manuf Technol Manag. 25(8):1195-1208.

Moldavska A, Welo T. 2019. A Holistic approach to corporate sustainability 
assessment : Incorporating sustainable development goals into sustainable manufacturing performance evaluation. J Manuf Syst. 50(August 2018):53-68.

Neto B, Kroeze C, Hordijk L, Costa C, Pulles T. 2009. Strategies to reduce the environmental impact of an aluminium pressure die casting plant: A scenario analysis. $\mathbf{J}$ Environ Manage. 90(2):815-830.

Neugebauer R, Altan T, Geiger M, Kleiner M, Sterzing A. 2006. Sheet metal forming at elevated temperatures. CIRP Ann - Manuf Technol. 55(2):793-816.

Nielsen. 2013. 50\% of global consumers surveyed willing to pay more for goods, services from socially responsible companies, up from 2011 [Internet]. Available from: https://www.nielsen.com/ie/en/press-room/2013/nielsen-50-percent-of-globalconsumers-surveyed-willing-to-pay-more-fo.html

Osakada K, Mori K, Altan T, Groche P. 2011. Mechanical servo press technology for metal forming. CIRP Ann - Manuf Technol. 60(2):651-672.

Pagone E, Jolly M, Salonitis K. 2016. The Development of a Tool to Promote Sustainability in Casting Processes. Procedia CIRP. 55:53-58.

Parsa MH, Pournia P. 2007. Optimization of initial blank shape predicted based on inverse finite element method. 43:218-233.

Paul ID, Bhole GP, Chaudhari JR. 2014. A review on Green Manufacturing : It's important, Methodology and its Application . MSPRO. 6(Icmpc):1644-1649.

Pavlovich LB, Alekseeva NM, Dolgopolov VP, Popov AA. 2004. ANTI-CORROSION PAINT AND VARNISH COATINGS EMPLOYING WASTES FROM COKE AND COAL CHEMICALS PRODUCTION. Metallurgist. 48(6):56-57.

Poozesh S, Akafuah N, Saito K. 2018. Effects of automotive paint spray technology on the paint transfer efficiency - a review. Proc Inst Mech Eng Part D J Automob Eng. 232(2):282-301.

Pusavec F, Krajnik P, Kopac J. 2010. Transitioning to sustainable production - Part I : application on machining technologies. J Clean Prod. 18(2):174-184.

Ramaprasad MS, Srinivas MN. 2012. Permanent Molding of Cast Irons - Present Status and Scope. In: Sci Technol Cast Process. Vol. 2. [place unknown]: InTech; p. 64. 
Available from: http://www.intechopen.com/books/science-and-technology-of-castingprocesses/permanent-molding-of-cast-irons-present-status-and-scope

Rauch E, Dallinger M, Dallasega P, Matt DT. 2015. Sustainability in Manufacturing through Distributed Manufacturing. Procedia CIRP. 29:544-549.

Roberts RE, Roberts JB. 1976. Reducing Solvent Emissions in Automotive Spray Painting. J Air Pollut Control Assoc. 26(4):353-358. Available from: http://www.tandfonline.com/doi/abs/10.1080/00022470.1976.10470261

Rossi M, Germani M, Zamagni A. 2016. Review of ecodesign methods and tools. Barriers and strategies for an effective implementation in industrial companies. J Clean Prod. 129:361-373. Available from: http://dx.doi.org/10.1016/j.jclepro.2016.04.051 Saavedra YMB, Iritani DR, Pavan ALR, Ometto AR. 2018. Theoretical contribution of industrial ecology to circular economy. J Clean Prod. 170:1514-1522. Available from: https://doi.org/10.1016/j.jclepro.2017.09.260

Safety in heat treatment. 2013. Int Heat Treat Surf Eng. 7(1):1-1. Available from: http://www.tandfonline.com/doi/full/10.1179/1749514813Z.00000000058

Salonitis K, Jolly M, Zeng B. 2017. Simulation Based Energy and Resource Efficient Casting Process Chain Selection: A Case Study. Procedia Manuf. 8(October 2016):6774. Available from: https://linkinghub.elsevier.com/retrieve/pii/S2351978917300124

Salonitis K, Jolly MR, Zeng B, Mehrabi H. 2016. Improvements in energy consumption and environmental impact by novel single shot melting process for casting. J Clean Prod. 137:1532-1542.

Salonitis K, Zeng B, Mehrabi HA, Jolly M. 2016. The Challenges for Energy Efficient Casting Processes. Procedia CIRP. 40:24-29.

Sangwan KS. 2011. Development of a multi criteria decision model for justification of green manufacturing systems. Int J Green Econ. 5(3):285. Available from: http://www.inderscience.com/link.php?id=44239

Schmitz N, Schwotzer C, Pfeifer H, Wuenning JG, Cresci E, Schneider J. 2017. Numerical investigation on post-combustion in a burner for heat treatment furnaces with a reducing gas atmosphere. Energy Procedia. 120:112-119. Available from: https://linkinghub.elsevier.com/retrieve/pii/S1876610217327273 
Schönfelder M, Wünning JG, Mickey S. 2016. Efficient Gas Heating Industrial Furnaces. :2016-2019.

Searson PC, Nagaskar P V., Latanision RM. 1999. Modern aspects of electrochemistry. In: White RE, Bockris JOM, Conway RB, editors. New York: Plenum Press.

Seliger G. 2007. Suatainability in Manufacturing. Springer Berlin Heidelberg New York.

Sharma A, Zhao F, Sutherland JW. 2015. Econological scheduling of a manufacturing enterprise operating under a time-of-use electricity tariff. J Clean Prod. 108:256-270.

Shi X, Chen J, Peng Y, Ruan X. 2004. A new approach of die shape optimization for sheet metal forming processes. 152:35-42.

Shubham, Charan P, Murty LS. 2018. Organizational adoption of sustainable manufacturing practices in India: integrating institutional theory and corporate environmental responsibility. Int J Sustain Dev World Ecol. 25(1):23-34. Available from: https://doi.org/10.1080/13504509.2016.1258373

Silva S, Valente RAF. 2012. Blank optimization in a stamping process - Influence of the geometry definition. Finite Elem Anal Des. 61:75-84.

Singh G, Siddique R. 2012. Effect of waste foundry sand (WFS) as partial replacement of sand on the strength, ultrasonic pulse velocity and permeability of concrete. Constr Build Mater. 26(1):415-422.

Singh PP, Madan J. 2016. A computer-aided system for sustainability assessment for the die-casting process planning. Int J Adv Manuf Technol. 87(5-8):1283-1298.

Sivapirakasam SP, Mohan S, Kumar MCS, Surianarayanan M. 2015. Welding fume reduction by nano-alumina coating on electrodes e towards green welding process. $\mathrm{J}$ Clean Prod. 108:131-144.

Sonawane GD, Gunjal SU. 2014. Review on Recent Trends \& Optimisation in Heat Treatment. IOSR J Mech Civ Eng. 11(3):52-58.

de Souza EC, Fernandes MR, Augustinho SCM, de Campos Franceschini Canale L, Totten GE. 2009. Comparison of Structure and Quenching Performance of Vegetable Oils. J ASTM Int. 6(9):102188. 
Sowinski A, Mehrani P. 2015. Impact of Addition of a Catalyst or Its Support on Reactor Wall Coating Due to Electrostatic Charging during Fluidization of Polyethylene. Ind Eng Chem Res.

Srinivasan K, Siddharth CSK, Kaarthic LVA, Thenarasu M. 2018. Evaluation of Mechanical Properties, Economic and Environmental Benefits of Partially Replacing Silica Sand with Biomass Ash for Aluminium Casting. Mater Today Proc. 5(5):1298412992.

Stanescu M, Stratton P. 2006. HEAT TREATMENT: PLAY IT SAFE! Heat Treat Prog. Steinboeck A, Wild D, Kugi A. 2013. Energy-efficient control of continuous reheating furnaces. [place unknown]: IFAC.

Stupnišek M. 2010. Heat treatment in an environmentally-friendly gas atmosphere. In: 65th ABM Int Congr 18th IFHTSE Congr 1st TMS/ABM Int Mater Congr. [place unknown]; p. 26-30.

Subject Guide Heat Treating. 2015. [place unknown].

Subramanian N, Gunasekaran A, Abdulrahman M, Liu C. 2014. Factors for implementing end-of-life product reverse logistics in the Chinese manufacturing sector. Int J Sustain Dev World Ecol. 21(3):235-245. Available from: http://dx.doi.org/10.1080/13504509.2014.906003

Toke LK, Kalpande SD. 2018. A framework of enabler's relationship for implementation of green manufacturing in Indian context. Int J Sustain Dev World Ecol. 25(4):303-311. Available from: https://doi.org/10.1080/13504509.2017.1393635 U.S. Bureau of Labor Statistics. 2019. Manufacturing: NAICS 31-33 [Internet]. Available from: https://www.bls.gov/iag/tgs/iag31-33.htm

UN. 2015. Sustainable Development Goals (SDGs) [Internet]. Available from: https://www.un.org/sustainabledevelopment/sustainable-development-goals/ UNEP. 1990. Resource Efficient and Cleaner Production [Internet]. [place unknown]. Available from: http://www.unep.org Valase K, Raut DN. 2019. Mediation analysis of multiple constructs in the relationship between manufacturing and technology and environmental constructs in structural 
equation model for sustainable manufacturing. Int J Adv Manuf Technol. 101(58):1887-1901. Available from: http://link.springer.com/10.1007/s00170-018-2979-5

Velichkin VA, Zavyalov VA. 2018. Optimization of Thermal Object Nonlinear Control Systems by Energy Efficiency Criterion. IOP Conf Ser Mater Sci Eng. 317:012015.

Villaume JE. 1979. Effects of Welding on Health Ewh 79. Miami: Amer Welding Society.

Vimal KEK, Vinodh S, Raja A. 2015. Modelling, assessment and deployment of strategies for ensuring sustainable shielded metal arc welding process - A case study. J Clean Prod. 93:364-377. Available from:

http://dx.doi.org/10.1016/j.jclepro.2015.01.049

Walczyk DF, Hardt DE. 1998. Discrete Dies for Sheet Metal Forming. J Manuf Syst. $17(6): 436-454$.

Wang JD, Chen JD. 1993. Acute and Chronic Neurological Symptoms Among Paint Workers Exposed to Mixtures of Organic Solvents. Environ Res. 61(1):107-116. Available from: http://linkinghub.elsevier.com/retrieve/pii/S0013935183710546 Wang ZG. 2004. Tribological approaches for green metal forming. 151:223-227. Xavier AF, Naveiro RM, Aoussat A, Reyes T. 2017. Systematic literature review of eco-innovation models: Opportunities and recommendations for future research. J Clean Prod. 149:1278-1302. Available from:

https://linkinghub.elsevier.com/retrieve/pii/S0959652617303712

Yang Y, Jong RA De, Reuter MA. 2007. CFD prediction for the performance of a heat treatment furnace. Prog Comput Fluid Dyn An Int J. 7(2/3/4):209.

Yazoghli-Marzouk O, Vulcano-Greullet N, Cantegrit L, Friteyre L, Jullien A. 2014. Recycling foundry sand in road construction-field assessment. Constr Build Mater. 61:69-78.

Yosri MH. 2018. Air ionizer application for electrostatic discharge ( ESD ) dust removal in automotive painting industry Air ionizer application for electrostatic discharge ( ESD ) dust removal in automotive painting industry. IOP Conf Ser Mater Sci Eng. 
Zeng B, Jolly M, Salonitis K. 2014. Manufacturing cost modeling of castings produced with CRIMSON process. TMS Annu Meet.:201-208. 